\title{
Characterization of a Florida plum introduction (USA) in Southern Brazil
}

\author{
Iohann Metzger Bauchrowitz ${ }^{1}$ (i) Clandio Medeiros da Silva ${ }^{2}$ (i) Gislaine Gabardo ${ }^{1^{*}}$ ([) \\ Cintia Sorane Good Kitzberger ${ }^{2}$ (i) Flávio Corrêa de Carvalho ${ }^{2}$ (i) \\ André Luiz de Oliveira de Francisco²
}

${ }^{1}$ Departamento de Fitotecnologia e Proteção Vegetal, Universidade Estadual de Ponta Grossa (UEPG), 84030-900, Ponta Grossa, PR, Brasil. E-mail: gislainegabardo2007@yahoo.com.br. "Corresponding author.

${ }^{2}$ Instituto de Desenvolvimento Rural do Paraná (IDR-Paraná), Ponta Grossa, PR, Brasil.

\begin{abstract}
Stone fruit cultivation is an alternative income for rural producers in Brazil, mainly for the southern region. In the specific case of plums, the lack of varieties adapted to the climatic conditions of this region is an obstacle that the research needs to resolve. In this context, the work aimed to evaluate the behaviour of the Japanese plum genotype FLA3-3 from the breeding program of the University of Florida (USA) in Ponta Grossa, Parana, Brazil, during the years 2013, 2014 and 2015. The experimental design used was entirely random. Twenty plants of the genotype under study were used, each one being a repetition. The characteristics evaluated in the field were the flowering and fruiting cycles according to the plant phenology. Physical analyzes of the fruits were carried out in the laboratory: average mass (pulp and seeds) and diameter and chemical analyze: total soluble solids, total titratable acidity and ratio. The results confirm that the genotype is precocious and the fruit harvest begins in October / November. It is adapted to the climatic condition of the municipality of Ponta Grossa, Parana, Brazil, in addition to presenting fruits within the commercial standards sought by producers and consumers. It is a viable alternative for rural producers in the region.
\end{abstract}

Key words: Prunus salicina Lindl., genotype, adaptation.

Caracterização de uma introdução de ameixa da Florida (EUA) no sul do Brasil

RESUMO: O cultivo da fruta com caroço é uma alternativa de renda para os produtores rurais do Brasil, principalmente da região Sul. No caso especifico das ameixas, a falta de variedades adaptadas às condições climáticas da região é um entrave que a pesquisa precisa superar. Nesse contexto, o trabalho teve como objetivo avaliar o comportamento do genótipo de ameixa japonesa FLA3-3 do programa de melhoramento da Universidade da Flórida (EUA) em Ponta Grossa, Paraná, Brasil, durante os anos de 2013, 2014 e 2015. O delineamento experimental usado foi inteiramente ao acaso. Foram utilizadas vinte plantas do genótipo em estudo, cada uma sendo uma repetição. As características avaliadas em campo foram os ciclos de floração e frutificação de acordo com a fenologia da planta. As análises fisicas dos frutos foram realizadas em laboratório: massa média (polpa e sementes) e diâmetro e análise química: sólidos solúveis totais, acidez total titulável e proporção. Os resultados confirmam que o genótipo é precoce e a colheita dos frutos inicia-se em outubro / novembro. Está adaptado às condições climáticas do município de Ponta Grossa, Paraná, Brasil, além de apresentar frutas dentro dos padrões comerciais buscados por produtores e consumidores, sendo uma alternativa viável para os produtores rurais da região.

Palavras-chave: Prunus salicina Lindl., genótipo, adaptação.

\section{INTRODUCTION}

The need for winter cold differentiates between the two centres of origin of plums grown worldwide, those of European origin (Prunus domestica L.) and those that have their center of origin in China known as Japanese plums (Prunus Salicina Lindl), the former need cold winter (temperature $\leq 7.2{ }^{\circ} \mathrm{C}$ ) above 720 hours and the second is adapted to conditions below this value (HAWERROTH et al., 2010).
They are also differentiated by the colour, size and shape of the fruits, the Japanese plum varies its color between shades of yellow, red, purple, blue and black, having large fruits of rounded oblate shape. At the same time, the European one presents a paler colouration of its fruits, ranging from yellow-green to blue-violet, with medium size and elliptical shape (TAITI et al., 2019).

In Brazil, the main varieties of plum cultivated are those of Japanese origin, mainly due to their lower need for winter cold (HAUAGGE \& 
BRUCKNER 2002). Even using Japanese plums, there are few cultivated varieties of this group, because the country has only in the south region, and some areas of the southeast region have a climate compatible with the needs of the crop (GUERRA et al., 2020). Another factor that can interfere with fruit production is the climate changes that have been occurring, requiring studies on the agronomic performance of new cultivars (MAYER et al., 2019).

Few plum cultivars are available to rural producers in Brazil (MARTINAZZO et al., 2013; BAUCHROWITZ et al., 2019; GABARDO et al., 2020). Suppose there is a need for breeding programs to launch new options (DALBÓ et al., 2018; GABARDO et al., 2021). The characterization of new plum introductions represents a gain both for breeding programs and directly for small and large rural producers.

Fruit growing in Brazil has been showing a significant increase in its growth levels, either in the planted area or in the quantity of fruits produced. However, the national production of plum is not enough to supply the demand of the domestic market, serving approximately $30 \%$ of the annual volume consumed in the country (Secretaria de Comércio Exterior - SECEX 2016). Being necessary to import the product from neighboring countries like Argentina and Chile (FAO, 2019). What characterizes a deficient market, indicating good potential for expansion to culture in Brazil (EIDAM et al., 2012).

Combining the need for work on the adaptation of new varieties to climatic conditions and the potential for expansion of the crop, there is a need for studies on new introductions of plum in Brazil, and their viability for rural producers. In this context, this work aimed to evaluate the Japanese plum genotype FLA3-3 of the breeding program of the University of Florida (USA) introduced in the plum breeding program of the Agronomic Institute of Paraná (IAPAR) in the climatic conditions of Ponta Grossa, Paraná, Brazil, during 2013, 2014 and 2015.

\section{MATERIALS AND METHODS}

The experiment was carried out at the Regional Research Pole of the IAPAR, located on the banks of BR-376, in the city of Ponta Grossa, Paraná, Brazil, geographically located at $25^{\circ} 13$ 'S latitude and $50^{\circ} 09^{\prime} \mathrm{W}$, with an approximate altitude of $850 \mathrm{~m}$. The climate of the region according to the Koppen classification is of the $\mathrm{Cfb}$ type, humid subtropical, with an average annual temperature of $18{ }^{\circ} \mathrm{C}$ and average annual precipitation of approximately $1.550 \mathrm{~mm}$ (IAPAR, 2019a). Meteorological data were collected at the on-site meteorological station (Figure 1).

The experiment was carried out from May to December 2013, 2014 and 2015. The genotype analyzed is the introduction FLA3-3, produced in the United States, by the University of Florida (SHERMANN \& BECKMAN 2002). Twenty plants of the genotype under study were used, each one being a repetition, evaluations were carried out within eight months, visiting the plants twice a week to obtain data on the beginning of flowering and fruiting. Phenological assessment scarried out in: beginning of flowering, falling petals, beginning of fruiting and harvest season.

When the fruits reached physiological maturity, for physicochemical evaluations, 200 fruits were collected each year, collected random. The following were evaluated: a) diameter (DM), performed manually with the aid of a caliper and classification of the fruit caliber (Table 1); b) total mass (MF), core mass (MC) and pulp mass (MP), using an analytical balance.

The following chemical analyzes were also performed: a) Total titratable acidity (TTA), stipulated in $2 \mathrm{ml}$ of fruit pulp juice in $10 \mathrm{ml}$ of water, titrated with a $0.1 \mathrm{~N} \mathrm{NAOH}$ solution, until reaching a $\mathrm{pH}$ of 8.1 , expressing the results as a percentage of malic acid; b) total soluble solids (SST) determined with a manual refractometer (RT-90 ATC), correcting its temperature to $20{ }^{\circ} \mathrm{C}$ and expressing the result in ${ }^{\circ}$ Brix; c) ratio (RAT) determined by the relationship between SST / ATT. The data were submitted to the F test by the SISVAR 5.6 program, and when significant, the Tukey mean comparison test at 5\% significance was performed.

\section{RESULTS AND DISCUSSION}

The full flowering of the FLA 3-3 genotype occurred between the months of July and August, in the three years (Table 2). In 2015 the flowering cycle was anticipated, and consequently full bloom. In 2015 , there was an unusual, winter, accumulating 48 hours of cold, while in the years 2013 and 2014, the accumulated hours of cold were 220 and 104 hours, respectively (IAPAR, 2019b).

The negative result of the exposure of plum plants to high temperatures is dependent on the intensity and time of exposure, as plants exposed for two hours at temperatures around $24^{\circ} \mathrm{C}$, can already suffer harmful consequences to their development due to the nullification of the cold (MELKE, 2015). 


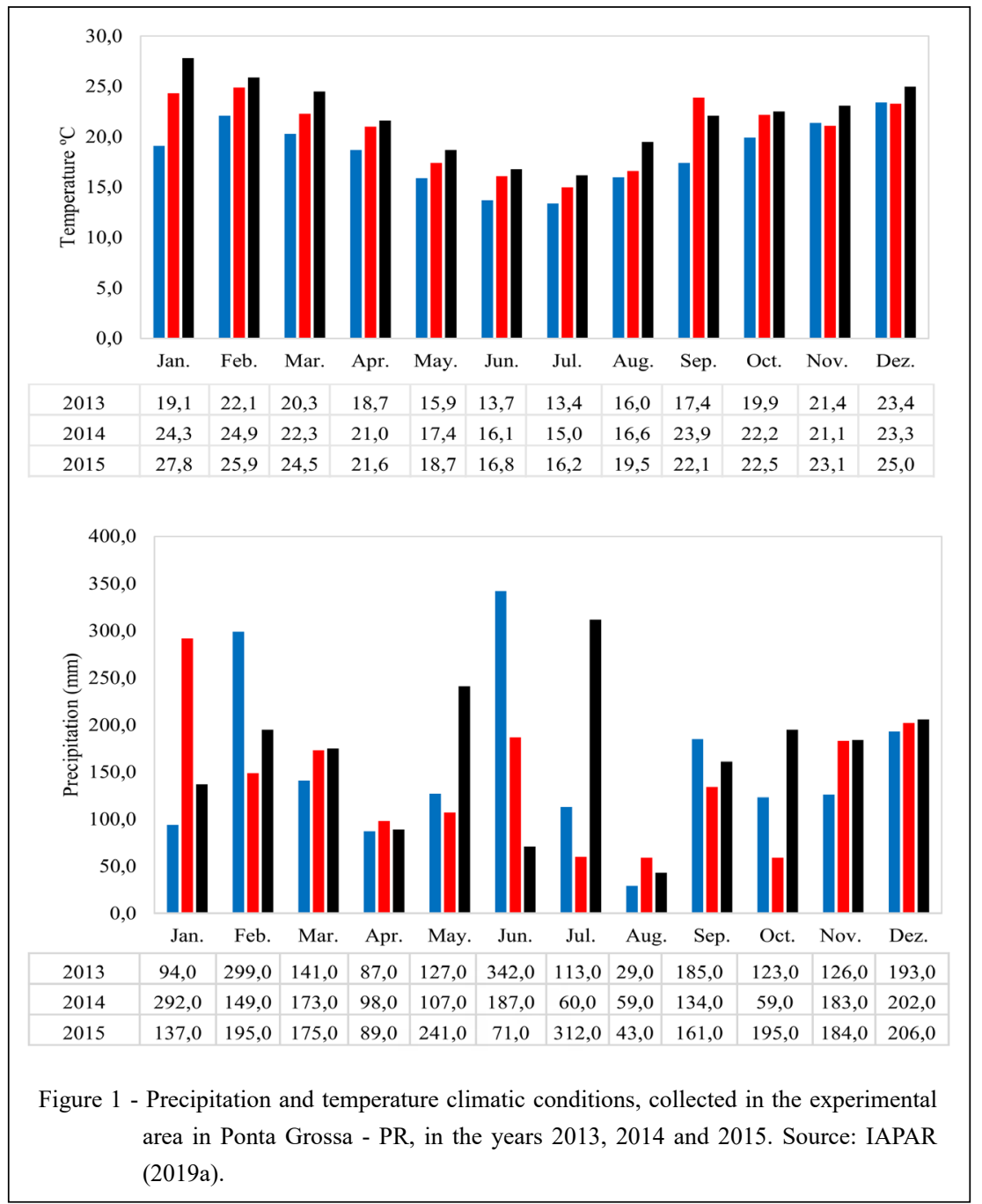

According to BAUCHROWITZ et al. (2019) a plum genotype may present variability in the stages of the beginning of flowering, drop of petals, beginning of fruiting and harvest, related to heterogeneous climatic conditions in each harvest, as they have a direct effect on the phenological cycle of this fruit tree, due to your need in winter cold, justifying the data obtained in the present experiment (Table 2).

The date of full flowering is of great importance in determining the point or time when the fruits can be harvested. However, this method is not highly accurate, interfering mainly when working with plum varieties and different locations (SILVA et al., 2008). The definition of cycles, whether flowering or harvesting, is of great importance mainly because they are closely related to the adaptation of varieties to different regions.

The harvest took place between 11, 25 and 27 October 2013, 2014 and 2015, respectively (Table 2). Results similar to those obtained by OLIVEIRA (2011) in Delfim Moreira-Minas Gerais, who evaluated the Gulfblaze plum, with the harvest started on October 20th. Unlike the result obtained by OLIVEIRA et al. (2019), where the cultivar Gulfblaze had its harvest in Maria da Fé - Minas Gerais on December 20, showing the difference in the adaptation of the crop in different climatic conditions.

The flowering duration of the FLA 3-3 genotype averaged 26 days (Table 3 ). In work carried out by MALGARIN et al. (2005) using the Reubennel plum in the Petrolina-Pernambuco region, it was 
Table 1 - Commercial classification of Japanese plum fruits, in different calibers according to the diameter of the fruit. Source: PAVANELLO \& AYUB (2012).

\begin{tabular}{lc}
\hline Caliber & Fruit diameter (Centimeters) \\
\hline Caliber I & $2.5-3.0$ \\
Caliber II & $3.0-3.5$ \\
Caliber III & $3.5-4.0$ \\
Caliber IV & $4.0-4.5$
\end{tabular}

obtained a number of days necessary for the 18day complete flowering cycle. There is a difference between genotypes.

Regarding the fruiting cycle characteristic, the introduction of FLA 3-3 presented an average cycle of approximately 94 days (Table 3). Similar results to cultivars América, Methley and Irati, with cycles of 94.2, 92.4 and 99.2 days, respectively, when grown in Pelotas-Rio Grande do Sul (DANNER et al., 2010). OLIVEIRA et al. (2011) obtained a similar result with the cultivar Reubennel, which took 99 days to complete its fruiting cycle in Maria da Fé-Minas Gerais.

Regarding the average fruit mass of the FLA 3-3 introduction (Table 4), the values ranged from 69.67 to $55.99 \mathrm{~g}$, higher than those obtained by OLIVEIRA et al. (2019) who found fruits with 60.0 and $41.1 \mathrm{~g}$ of average mass, for Gulfblaze and Reubennel cultivars, respectively, when grafted on Okinawa peach rootstock.

BAUCHROWITZ et al. (2019) obtained from fruits of the introduction FLA 8-3 the mass of the stones between 5.60 to $6.50 \mathrm{~g}$. In the present experiment, similar values were obtained (5.05 to $5.67 \mathrm{~g})$. Core mass is of secondary importance because it is related mainly to the production of new plants than to the actual commercialization of the fruit itself (BANDEIRA et al., 2011).
In this work, we use the mass of the stone to help obtain the amount of mass of the pulp, because through the total mass of the fruits excluding the mass of the stones, the mass of the pulp of the fruits can be obtained. The pulp mass of the fruits has great commercial importance, as it is a characteristic related to the amount of usable material produced in the fruits and which will be consumed (KITZBERGER et al., 2017).

In the three harvests $(2013,2014$ and 2015), the values obtained for the diameter of the fruits of the introduction FLA 3-3 were 5.1, 4.8 and $4.4 \mathrm{~cm}$, respectively (Table 4 ), receiving the classification of caliber IV, a fruit of good acceptance and which is in great demand by consumers (PAVANELLO \& AYUB 2012).

On a commercial scale, the average size of the fruits has a direct influence on the viability of an orchard, impacting productivity and profitability, as it can increase production per plant and the price negotiated for the largest size fruits on the market (HF BRASIL 2016).

AYUB et al. (2019) determined that the Japanese plum of the accessions G52, G7 and G53 did not exceed the value of $4.8 \mathrm{~cm}$. Fruits of the cultivar Poli Rosa have an average diameter of 4.58 $\mathrm{cm}$ (MANSOURI et al., 2010). In the cultivars,

Table 2 - Phenological data (full bloom and fruit harvest date) for the Japanese plum genotype FLA 3-3 during the years 2013, 2014 and 2015 in Ponta Grossa-Paraná, Brazil.

\begin{tabular}{ccc}
\hline Year & Full Bloom & Harvest Date \\
\hline 2013 & $07 / 25 / 2013$ & $10 / 25 / 2013$ \\
2014 & $08 / 12 / 2014$ & $10 / 11 / 2014$ \\
2015 & $07 / 17 / 2015$ & $10 / 27 / 2015$ \\
\hline
\end{tabular}


Table 3 - Data on the number of days in the flowering and fruiting cycles of the Japanese plum genotype FLA 3-3 during the years 2013, 2014 and 2015 in Ponta Grossa-Paraná, Brazil.

\begin{tabular}{lcc}
\hline Year & Flowering Cycle (Days) & Fruiting Cycle (Days) \\
\hline 2013 & 23 & 91 \\
2014 & 28 & 90 \\
2015 & 26 & 101 \\
Average & $\cong 26$ & $\cong 94$
\end{tabular}

Stanley and Tuleu Gras the diameter of the fruits can vary between 3.6 to 5.4 and 3.0 to $4.8 \mathrm{~cm}$, respectively (VLAIC et al., 2014). Demonstrating that the introduction of FLA 3-3 presents fruits with a diameter similar to cultivars recognized in the market.

Regarding the chemical attributes of the fruits of the FLA 3-3 introduction, similar results were obtained in the years 2013 and 2014 (Table 5). Regarding total soluble solids (SST), higher values were obtained in the years 2013 and 2014, years that presented favorable climatic conditions, when compared to 2015 , the year in which there was a significant reduction in SST (Table 5).

The change in SST in the period of the experiment may have occurred due to some factors, mainly climatic since MALGARIM et al. (2005) cite that SST production is favored by the incidence of sunlight under the fruits. In the present study for the year 2015, there was an atypical spring season, with a very high amount of rainfall (Figure 1), which may have affected the amount of lighting available for the production of sugar in the fruits.

Assessing the physicochemical characteristics of ripe fruits of different Japanese plum cultivars grown in Italy, TAITI et al. (2019) indicated that the cultivars Dofi Gindy, Laroda, Black Diamond, Fortune, Golden Plum, Settembrine and Angeleno could reach SST amounts of 13.4, 8.70, 11.75, 14.55, 13.87, 15.90 and $15.23^{\circ}$ Brix, respectively. While fruits of the Black Splendor cultivar have between 12.9 to $13.1^{\circ}$ Brix, depending on the point of the harvest of the fruits (MINAS et al., 2013). They were denoting the overcoming, similarity inferiority of the fruits of the introduction FLA 3-3 in relation to its SST in relation to the cultivars analyzed by the authors mentioned above.

In the fruits of this Introduction, when we analyze the amount of acidity in the fruits, it is possible to observe that in 2014 there were higher values of total titratable acidity (ATT) when purchased with the data obtained in 2013 and 2015 (Table 4). This variation in the amount of ATT in the fruits of the same genotype can be influenced primarily by the point of harvest or by some change in the cycle during the year (SALAZAR et al., 2017).

Already, plum fruits of the cultivar Sanhua have values referring to the acidity of the fruits varying between 1.14 to $2.34 \%$, depending on the color of the pulp of them during their phenological cycle (LI et al., 2019). In Black Diamond and Angeleno cultivars,

Table 4 - Average data from physical fruit evaluations: fruit mass (MF), seed mass (MC), pulp mass (MP) and fruit diameter (DM) the Japanese plum genotype FLA 3-3 during the years 2013, 2014 and 2015 in Ponta Grossa-Paraná, Brazil.

\begin{tabular}{|c|c|c|c|c|}
\hline Year & MF (grams) & MC (grams) & MP (grams) & $\mathrm{DM}(\mathrm{cm})$ \\
\hline 2013 & $69.67 \mathrm{c}^{*}$ & $5.46 \mathrm{~b}$ & $64.21 \mathrm{c}$ & $5.10 \mathrm{c}$ \\
\hline 2014 & $66.78 \mathrm{~b}$ & $5.05 \mathrm{a}$ & $61.73 \mathrm{~b}$ & $4.80 \mathrm{~b}$ \\
\hline 2015 & $55.99 \mathrm{a}$ & $5.67 \mathrm{c}$ & $49.32 \mathrm{a}$ & $4.40 \mathrm{a}$ \\
\hline
\end{tabular}

*Means followed by the same letters in the column do not differ significantly by the Tukey test $(\mathrm{P}<0.05)$. 
Table 5 - Average data of chemical evaluations of fruits: total soluble solids (SST), total titratable acidity (ATT), ratio (RAT), the Japanese plum genotype FLA 3-3 during the years 2013, 2014 and 2015 in Ponta Grossa-Paraná, Brazil.

\begin{tabular}{lccc}
\hline Year & SST $\left({ }^{\circ}\right.$ Brix $)$ & ATT $(\%)$ & RAT \\
\hline 2013 & $13.00 \mathrm{~b}^{*}$ & $1.10 \mathrm{c}$ & $11.81 \mathrm{~b}$ \\
2014 & $13.00 \mathrm{~b}$ & $1.56 \mathrm{~b}$ & $8.33 \mathrm{a}$ \\
2015 & $8.9 \mathrm{a}$ & $0.43 \mathrm{a}$ & $20.69 \mathrm{c}$ \\
\hline
\end{tabular}

${ }^{*}$ Means followed by the same letters in the column do not differ significantly by the Tukey test $(\mathrm{P}<0.05)$.

ATT can vary between 3.40 to $3.54 \%$ and 5.10 to 5.20 (IMRAK et al., 2019). Variations in fruit acidity are observed in different peach genotypes when analyzed for selection of future cultivars between 0.52 to $0.84 \%$, this variation occurs due to genetic differences between the genotypes (WAGNER JÚNIOR et al., 2011).

The amount of ratio (RAT) present in the fruits of the introduction FLA 3-3 (Table 5) varied between the analyzes carried out in the different years of study, mainly due to changes that occurred in the characteristics of SST and ATT, which directly influence the amount of Fruit RAT.

The amount of RAT in the plum fruits of the introduction FLA 3-3 for the year 2014, were lower than those obtained by TAITI et al. (2019) in all cultivars already mentioned above, with values ranging from 10 to 32.45 for cultivars Laroda and Settembrine, respectively.

In the year 2015, the amount of RAT in the fruits, presented high values of 20.69 (Table 5), this fact occurred mainly due to the low amount of acidity that was present in the fruits. The cultivar Songold has variation in the amount of ratio of fruits depending on the point of maturity of the fruits, varying between 9.25 to 13.8 when the fruits are harvested at the time of fruit maturation (VELARDO-MICHARET et al., 2017). The cultivar Sanhua has values of 7.98130 days after full bloom (LI et al., 2019), while the introduction of FLA 3-3 showed higher values in the three years evaluated.

\section{CONCLUSION}

The introduction of FLA 3-3 during 2013, 2014 and 2015 has the potential to adapt to climatic conditions in the municipality of Ponta Grossa, Paraná, Brazil, producing fruit with commercial quality. It can be recommended for planting in the orchards of producers in the region. It is contributing directly to the Brazilian fruit culture with the insertion of new cultivars in Brazil.

\section{ACKNOWLEDGEMENTS}

This study was financed in part by the Coordenação de Aperfeiçoamento de Pessoal de Nível Superior - Brasil (CAPES) - Finance Code 001 .

\section{DECLARATION OF CONFLICTS OF INTEREST}

The authors declare no conflict of interest. The founding sponsors had no role in the design of the study; in the collection, analyses, or interpretation of data; in the writing of the manuscript, and in the decision to publish the results.

\section{AUTHORS' CONTRIBUTIONS}

The authors contributed equally to the manuscript.

\section{REFERENCES}

AYUB, R. A. et al. Ammonia thiosulfate in Japanese plum tree thinning. Revista Brasileira de Fruticultura, Jaboticabal, v. 41, n.5, 2019. Available from: <https://doi.org/10.1590/010029452019543>. Accessed: Jan. 12, 2020. doi: 10.1590/010029452019543

BANDEIRA, J. D. M. et al. Physiological characterization of reproductive compatibility of Japanese plum. Pesquisa Agropecuária Brasileira, Brasília, v. 46, n. 8, p. 860-867, 2011. Available from: $<$ https://doi.org/10.1590/S0100204X2011000800011>. Accessed: Jan. 10, 2020. doi: 10.1590/ S0100-204X2011000800011.

BAUCHROWITZ, I. M. et al. Comportamento fenológico e qualidade dos frutos de genótipos de ameixa japonesa no municípío de Ponta Grossa-PR. Brazilian Journal of Applied Technology for Agricultural Science, v. 12, n. 2, 2019. Available from: $\quad<$ http://periodicos.unifil.br/index.php/Revistateste/article/ view/1170>. Accessed: Feb. 21, 2020.

Ciência Rural, v.52, n.9, 2022. 
DALBÓ, M. A. et al. SCS 438 Zafira-a new plum cultivar resistant to leaf scald (Xylella fastidiosa). Crop Breeding and Applied Biotechnology, v. 18, n. 2, p. 229-233, 2018. Available from: $<$ https://doi.org/10.1590/1984-70332018v18n2c33>. Accessed: Mar. 27, 2021. doi: 10.1590/1984-70332018v18n2c33.

DANNER, M. A. et al. Fruit weight and cycle length repeatability of plum and peach trees. Pesquisa Agropecuária Brasileira, v. 45, n. 8, p. 872-878, 2010. Available from: <https://doi.org/10.1590/ S0100-204X2010000800013>. Accessed: Apr. 18, 2020. doi: 10.1590/S0100-204X2010000800013.

EIDAM, T. \& PAVANELLO, A. P. Ameixeira no Brasil. Revista Brasileira de Fruticultura, v. 34(1), i-i. 2012. Available from: $<$ https://doi.org/10.1590/S0100-29452012000100001>. Accessed: Aug. 25, 2020. doi: 10.1590/S0100-29452012000100001.

FAO. Area harvested and production of plums and sloes in 2016. 2019. Available from: < http://www.fao.org/faostat/en/\#data/QC $>$. Accessed: Dec. 17, 2019.

GABARDO, G. et al. Selection of plum genotypes for resistance to leaf scald. Summa Phytopathologica, v. 46, p. 305-307, 2020. Available from: <https://doi.org/10.1590/0100-5405/238868>. Accessed: Nov. 16, 2020. doi: 10.1590/0100-5405/238868.

GABARDO, G. et al. Plum leaf scald: characteristics of the causative agent, symptoms, dissemination, control and prevention. Revista Brasileira de Fruticultura, v. 43, 2021. Available from: $<$ https://doi.org/10.1590/0100-29452021009>. Accessed: Aug. 17, 2021. doi: 10.1590/0100-29452021009.

GUERRA, M.E. et al. Self-(in) compatibility, S-RNase allele identification, and selection of pollinizers in new Japanese plum-type cultivars. Scientia Horticulturae, v. 2, n. 6, p. 10880-10902, 2020. Available from: <https://doi.org/10.1016/j. scienta.2019.109022>. Accessed: Jul. 17, 2020. doi: 10.1016/j. scienta.2019.109022.

HAUAGGE, R. \& BRUCKNER, C. H. Macieira In: Bruckner, C. H. Melhoramento de fruteiras de clima temperado. Viçosa: UFV, 2002. p. 27

HAWERROTH, F. J. et al. (2010). Dormência em frutíferas de clima temperado. Embrapa Clima Temperado-Documentos (INFOTECA-E).

HF BRASIL. Hortifruti Brasil. Available from: < http://www. hfbrasil.org.br/en/average-prices-database-ofhorticultural.aspx? produto $=10 \&$ regiao $\% 5 \mathrm{~B} \% 5 \mathrm{D}=91 \&$ periodicidade $=$ mensal\&ano inicial $=$ 2015\&ano_final=2016>. Accessed: Apr. 23, 2016.

IAPAR - Instituto Agronômico do Paraná. Atlas climático do Paraná. 2019a. Available from: <http://www.iapar.br/modules/ conteudo/conteudo.php?conteudo=2533>. Accessed: Dec. 12, 2019.

IAPAR - Instituto Agronômico do Paraná. Horas de frio em ponta grossa. 2019b. Available from: <http://www.iapar.br/modules/ conteudo/conteudo.php?conteudo=2042> . Accessed: Dec. 18, 2019.

İMRAK, B. et al. Effects of Different pruning Systems on Fruit Yield and Quality in Plum (Prunus salicina Lindl.). Turkish Journal of Agriculture-Food Science and Technology, v. 7, n. 11, p. 1872-1876, 2019. Available from: <https://doi.org/10.24925/ turjaf.v7i11.1872-1876.2809>. Accessed: Aug. 17, 2020. doi: 10.24925/turjaf.v7i11.1872-1876.2809.
KITZBERGER, C. S. G. et al. Physicochemical and sensory characteristics of plums accesses (Prunus salicina). AIMS AgriFood, v. 2, n.1, p. 101-112, 2017. Available from: <https:// doi.org/10.3934/agrfood.2017.1.101>. Accessed: Feb. 12, 2021. doi: 10.3934/agrfood.2017.1.101.

LI, Q. et al. Phytochemicals accumulation in Sanhua plum (Prunus salicina L.) during fruit development and their potential use as antioxidants. Journal of agricultural and food chemistry, v. 67, n. 9, 2459-2466, 2019. Available from: <https://doi.org/10.1021/acs. jafc.8b05087>. Accessed: Jul. 09, 2020. doi: 10.1021/acs.jafc.8b05087.

MALGARIM, M. B. et al. Stage of maturation and temperature variation during the storage on postharvest quality of plums cv. Amarelinha. Revista Brasileira de Fruticultura, v. 27, n.1, p.29-35, 2005. Available from: <https://doi.org/10.1590/S010029452005000100010>. Accessed: Sep. 04, 2020. doi: 10.1590/ S0100-29452005000100010.

MANSOURI, Y. S. et al. Statistical modeling of pomegranate (Punica granatum L.) fruit with some physical attributes. Journal of Food Processing Technology, v. 1, p. 1-4, 2010. Available from: <https://doi.org/10.4172/2157-7110.1000102>. Accessed: Jul. 17, 2020. doi: 10.4172/2157-7110.1000102.

MARTINAZZO, E. G. et al. Photosynthetic activity in japanese plum under water deficit and flooding. Ciência Rural, v. 43, n. 1, p. 35-41, 2013. Available from: <https://doi.org/10.1590/S010384782012005000126>. Acessed: Aug. 20, 2020. doi: 10.1590/ S0103-84782012005000126.

MELKE, A. The physiology of chilling temperature requirements for dormancy release and bud-break in temperate fruit trees grown at mild winter tropical climate. Journal of Plant Studies, v. 4, n. 2, 2015. Available from: <http://dx.doi.org/10.5539/jps.v4n2p110>. Accessed: Sep. 15, 2020. doi: 10.5539/jps.v4n2p110.

MINAS, I. S. et al. Postharvest handling of plums (Prunus salicina Lindl.) at $10 \mathrm{C}$ to save energy and preserve fruit quality using an innovative application system of 1-MCP. Postharvest Biology and Technology, v. 76, p. 1-9, 2013. Available from: $<$ https://doi. org/10.1016/j.postharvbio.2012.08.013>. Accessed: Jul. 17, 2020. doi: 10.1016/j.postharvbio.2012.08.013.

OLIVEIRA, M. C. D. et al. Selection of promising plum cultivars for the Mantiqueira Mountain Range. Revista Ceres, v. 58, n.4, p.531-535, 2011. Available from: <https://doi.org/10.1590/S0034737X2011000400019>. Accessed: Jul. 20, 2020. doi: 10.1590/ S0034-737X2011000400019.

OLIVEIRA, J. A. A. et al. Performance of interstocks in the plant development and fruit quality of plum trees. Acta Scientiarum. Agronomy, v. 41. 2019. Available from: <https://doi.org/10.4025/ actasciagron.v41i1.39928>. Accessed: Jul. 25, 2020. doi: 10.4025/ actasciagron.v41i1.39928.

PAVANEllo, A. P. \& AYUB, R. A. Application of ethephon thinning in chemical plum and its effect on productivity. Revista Brasileira de Fruticultura, v.34, n.1, p. 309-316, 2012. Available from: $\quad<$ https://doi.org/10.1590/S0100-29452012000100040>. Accessed: Jul. 17, 2020. doi: 10.1590/S0100-29452012000100040.

SALAZAR, J. A. et al. Genotyping by sequencing for SNP-based linkage analysis and identification of QTLs linked to fruit quality traits in Japanese plum (Prunus salicina Lindl.). Frontiers in Plant Science, v. 8, n. 3, p. 465-476, 2017. Available from: <https:// 
doi.org/10.3389/fpls.2017.00476>. Accessed: Jul. 17, 2020. doi: $10.3389 /$ fpls.2017.00476

Secretaria de Comércio Exterior (SECEX). Available from: $<$ http://portal.siscomex.gov.br/legislacao/orgaos/secretaria-decomercio-exterior-secex>. Accessed: Jan. 21, 2019

SHERMAN, W. B., \& BECKMAN, T. G. (2002, August). Climatic adaptation in fruit crops. In XXVI International Horticultural Congress: Genetics and Breeding of Tree Fruits and Nuts 622 (p. 411-428). Available from: <https://doi.org/10.17660/ ActaHortic.2003.622.43>. Accessed: Jul. 17, 2020. doi 10.17660/ ActaHortic.2003.622.43.

SILVA, F. P. et al. Productive performance of japanese plum cultivars (Prunus salicina Lindl.) in Caldas, Minas Gerais State. Revista Ciência Agronômica, v. 39, n. 2, p. 281-286, 2008 Available from: <http://www.ccarevista.ufc.br/seer/index.php/ ccarevista/article/view/61>. Accessed: Jan. 20, 2019.

TAITI, C. et al. Fruit aroma and sensorial characteristics of traditional and innovative Japanese plum (Prunus salicina Lind1.) cultivars grown in Italy. European Food Research and
Technology, v.2, n. 12, p. 2655-2668, 2019. Available from: $<$ https://doi.org/10.1007/s00217-019-03377-y>. Accessed: Jan. 19, 2021. doi https://doi.org/10.1007/s00217-019-03377-y.

VELARDO-MICHARET, B. et al. Effect of ripening stage, 1-MCP treatment and different temperature regimes on long term storage of 'Songold'Japanese plum. Scientia Horticulturae, v. 214, p. 233-241, 2017. Available from: $<$ https://doi.org/10.1016/j. scienta.2016.11.043>. Accessed: Jul. 28, 2020. doi: 10.1016/j. scienta.2016.11.043.

VLAIC, R. A. et al. Physico-Chemical Changes during Growth and Development of Three Plum Varieties. Bull. UASVM Food Science Technology, v. 71, n. 2, 2014. Available from: $<$ https:// doi.org/10.15835/buasvmen-fst:10686>. Accessed: Aug. 09, 2020. doi: 10.15835 /buasvmen-fst:10686.

WAGNER JÚNIOR, A. et al. High fruit quality peach tree progenies and parents selection. Revista Brasileira de Fruticultura, Jaboticabal, v. 33, n.1, p.170-179, 2011. Available from: <https://doi.org/10.1590/S010029452011005000044>. Accessed: Jul. 17, 2020. doi: 10.1590/ S0100-29452011005000044. 